\title{
Direct arylation and Suzuki-Miyaura coupling of imidazo $[1,2-a]$ pyridines catalyzed by (SIPr)Pd(allyl)Cl complex under microwave-irradiation
}

\author{
Abdelmoula El Abbouchi ${ }^{1}$, Jamal Koubachi ${ }^{2, *}$, Nabil El Brahmi ${ }^{1}$ and Saïd El Kazzouli ${ }^{\text {,** }}$ \\ ${ }^{1}$ Euromed Research Center, Euromed Faculty of Engineering, Euromed University of Fes (UEMF), Route de \\ Meknes, 30000 Fes, Morocco \\ ${ }^{2}$ Faculté Polydisciplinaire de Taroudant, B.P 271, 83000 Taroudant, Laboratoire de Chimie Appliquée et \\ Environnement (LACAPE), Faculté des Sciences, Université Ibn Zohr d'Agadir, Morocco
}

\begin{abstract}
A short and practical arylation of imidazo[1,2-a]pyridine and imidazole derivatives with aryl halides or aryl boronic acids as coupling partners was successfully carried out using phosphine-free ( $\mathrm{SIPr}) \mathrm{Pd}(\mathrm{allyl}) \mathrm{Cl}$ as the catalyst [SIPr: (N,N'-bis(2,6-diisopropylphenyl)-4,5-dihydroimidazol-2-ylidene)] $((\mathrm{SIPr}) \mathrm{Pd}($ allyl $) \mathrm{Cl}$ complex). 3,6-disubstituted imidazo[1,2-a]pyridine and 5-substituted imidazole compounds were obtained in good to excellent yields in only $1 \mathrm{~h}$ under microwave-assisted $\mathrm{C}-\mathrm{H}$ arylation and Suzuki-Miyaura coupling reaction conditions.
\end{abstract}

Keywords: Direct arylation; Suzuki-Miyaura coupling; Imidazo[1,2-a]pyridine; Microwave-irradiation.

\section{Introduction}

Over the last decades, many substituted imidazo $[1,2-a]$ pyridine compounds are found to be biologically active ${ }^{1-5}$. For example, this heterocyclic system has been reported as melatonin receptor ligands 6, antiviral 7, antiulcer 8, antibacterial ${ }^{9}$, antifungal compounds ${ }^{10}$, agonist of benzodiazepine receptor ${ }^{11}$, calcium channel blocker ${ }^{12}$, $\beta$-amyloid formation inhibitor ${ }^{13}$, ligand for detecting $\beta$-amyloid ${ }^{14}$, herbicidal ${ }^{15}$, cyclindependent kinase (CDK) inhibitors ${ }^{16}$, GABAA receptor modulator ${ }^{17}$ and constitute a novel class of orally active nonpeptide bradykinin B2 receptor antagonists ${ }^{18}$. Moreover, it possesses inhibitory activity against cyclooxigenase-2 (COX-2) with high selectivity in relation to COX-1. The imidazo[1,2-a] pyridine is also present in pharmacologically important drugs such as Alpidem ${ }^{19}$, Zolpidem ${ }^{20}$ and Olprinone ${ }^{21}$.

During the last fifteen years, several methods for the formation of carbon-carbon bonds on imidazo[1,2-a] pyridine derivatives using transition metal catalysts have been reported ${ }^{22}$ such as Sonogashira, Heck, Negishi, Suzuki-Miyaura and Stille cross-coupling. In addition, $\mathrm{C}-\mathrm{H}$ arylation has proved extremely versatile and has found extensive use in natural products and heterocyclic synthesis 22,23 and is considered nowadays as a powerful addition to the classic palladium cross-coupling reactions.
$\mathrm{N}$-Heterocyclic carbenes (NHCs) have received a great deal of attention from a number of researchers over the past few decades. These ligands have been employed in a broad range of fields, including organocatalysis $^{24}$ and organometallic chemistry ${ }^{25}$. Many reports described the applications of the $[\mathrm{Pd}(\mathrm{NHC})]$ complexes as catalysts for SuzukiMiyaura coupling, Buchwald-Hartwig amination reaction, Kumada coupling, Sonogashira coupling, Heck reaction, Stille coupling, dehalogenation reactions as well as ketone arylation reactions ${ }^{26}$.

In contrast, they have been weakly applied in $\mathrm{C}-\mathrm{H}$ arylation reactions ${ }^{27}$. In this area, our group has a long-standing interest in $\mathrm{C}-\mathrm{H}$ activation of 6,5-fused heterocyclic system in general ${ }^{28}$ and imidazo[1,2-a] pyridine derivatives in particular ${ }^{29}$. In previous published works, we have reported a regioselective palladium-catalyzed C-3 (hetero)arylation 30a and $\mathrm{C}-3$ alkenylation ${ }^{31}$ of imidazo[1,2-a] pyridines. We have developed also a one-pot C-3/C-6 di-functionalization of imidazo[1,2- $a$ ] pyridines using sequential Suzuki/direct (hetero)arylation, Suzuki/Suzuki and Sonogashira/ Sonogashira crosscoupling reactions ${ }^{30 b, 32}$.

Herein, we wish to describe the efficacy and the ability of the allyl-[1,3-bis(2,6-diisopropylphenyl)4,5-dihydroimidazolidin-2-ylidene] chloropalladium (II) $[(\mathrm{SIPr}) \mathrm{Pd}($ allyl)Cl] catalytic system (Fig. 1) to 
catalyze direct arylation and Suzuki-Miyaura coupling reactions for the functionalization of imidazo[1,2-a] pyridine derivatives. Reactions were developed under microwave irradiation using aryl bromides to achieve direct arylation at position $\mathrm{C}-3$ and boronicacids as coupling partners to introduce aryls at position C-6. In is noticed that ( $\mathrm{SIPr}) \mathrm{Pd}($ allyl)Cl complex which is an air stable commercially available catalyst has proven a good efficiency in Buchwald-Hartwig amination ${ }^{33}$ as well as in ketone arylation reactions ${ }^{34}$.

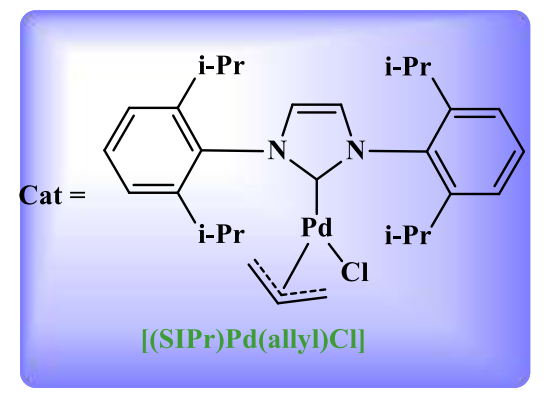

Figure 1. ( $\mathrm{SIPr}) \mathrm{Pd}($ allyl $) \mathrm{Cl}$ complex

\section{Results and Discussion}

At the outset of this investigation, the $\mathrm{C}-\mathrm{H}$ arylation reaction was carried out under the previously published conditions used for $\mathrm{Pd}(\mathrm{OAc})_{2}$-catalyzed direct arylation and heteroarylation of imidazo[1,2-a] pyridines at the $\mathrm{C} 3$-position $\left[130^{\circ} \mathrm{C}\right.$ for 1 hour ${ }^{30 \mathrm{a}}$. Thus, under microwaves irradiation, the reaction of imidazo[1,2-a] pyridine 1 (1 equiv.) with bromobenzene (1.2 equiv.) catalyzed by phosphinefree (SIPr)Pd(allyl)Cl complex ${ }^{33,34}(5 \mathrm{~mol} \%)$ in the presence of $\mathrm{KO} t \mathrm{Bu}$ (2 equiv.) as base at $150^{\circ} \mathrm{C}$ for $1 \mathrm{~h}$ was achieved in different solvents. Among the solvents screened, dioxane and DME gave the best yield (Scheme 1).

The optimized reaction conditions were then established as follow: imidazo[1,2-a] pyridine $\mathbf{1}$ (1 equiv.), bromobenzene (1.2 equiv.), $\mathrm{KO} t \mathrm{Bu}$ ( 2 equiv.), (SIPr)Pd(allyl)Cl complex $(5 \mathrm{~mol} \%)$ in dioxane or DME $(2 \mathrm{ml})$ at $150^{\circ} \mathrm{C}$ for $1 \mathrm{~h}$ under $\mathrm{MW}$ (Scheme 1). Under these conditions, either dioxane or DME as solvent led to the expected product $2^{30 a}$ in 84 and $82 \%$ yield, respectively (Scheme 1).

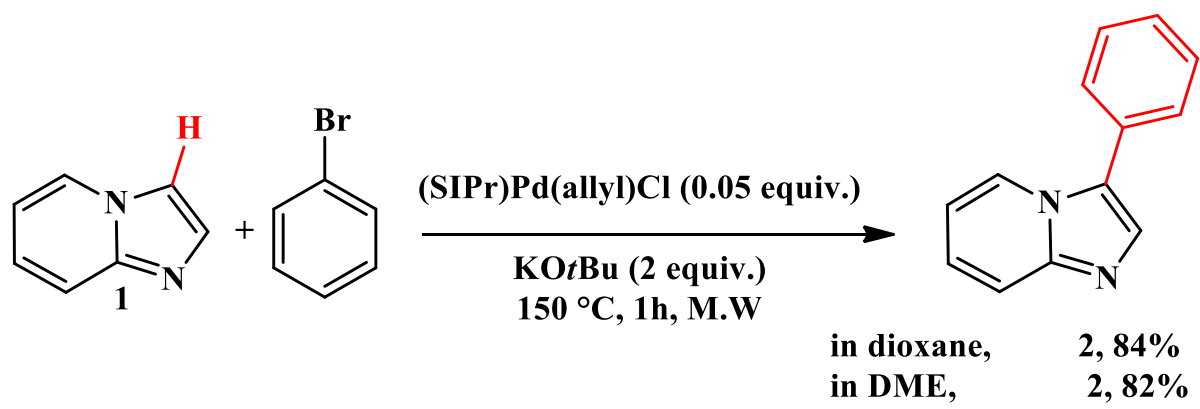

Scheme 1. Optimization of C-H arylation of imidazo[1,2-a] pyridine under microwave-irradiation with bromobenzene

With these reaction conditions in hand, we evaluated then the scope and limitations of our method using various imidazo[1,2-a] pyridine analogues (Table 1 ). When 4-bromotoluene, 3-bromotulene or 2-bromotoluene were used as coupling partners, the desired products $3-5$ were obtained in $78^{35}, 81^{30 a}$ and $75 \%{ }^{35}$ yields, respectively (entries 2-4, Table 1). This result shows no real impact of the position of the methyl group on the reaction yield. We also proved that the use of 2-iodotoluene instead of 2-bromotoluene did not improve significantly the reaction yield (76\% instead of $75 \%$, entries 4 and 5 , Table 1). The same result was observed when using either 4-iodonitrobenzene or 4-bromonitrobenzene as coupling partners (entries 6 and 7, Table 1). In these cases, the expected product 6 was isolated in 82 and $80 \%$ yield ${ }^{36}$, respectively.

Then, we decided to use 5-chloroimidazo[1,2-a] pyridine 7 as starting material. In this case, the reaction between 7 and bromobenzene led to the desired product $8^{30 a}$ in $77 \%$ yield showing very good tolerance to the presence of the choro group on the six membered ring (entry 8, Table 1). Good reaction yields were obtained using either 3-bromotoluene or 4-methoxybromobenzene as coupling partners which demonstrated that no effect of the use of electron with donating group or electron with drawing group on the reaction yield (compounds $9^{30 \mathrm{a}}$ and $\mathbf{1 0}{ }^{37}$, entries 9 and 10, Table 1 ). We also showed that the reaction is feasible when using bromoheteroaryls as coupling partners. Thus, the reaction between $\mathbf{1}$ and either 3-bromopyridine or 2-bromothiophene led to expected products $11^{30 \mathrm{a}}$ and $12{ }^{38}$ in 69 and $60 \%$ yields, respectively (entries 11 and 12, Table 1).

Finally, we showed that the reaction conditions can be applied to achieve the direct arylation of imidazoles. In this case, 1,2-dimethyl- $1 H$-imidazole 13 was selected as starting material and bromobenzene as coupling partner which led to the expected arylated product $\mathbf{1 4}{ }^{39}$ in $63 \%$ yield (entry 13, Table 1). 
Table 1. Direct arylation of imidazo[1,2-a] pyridines and imidazole ${ }^{\text {a }}$

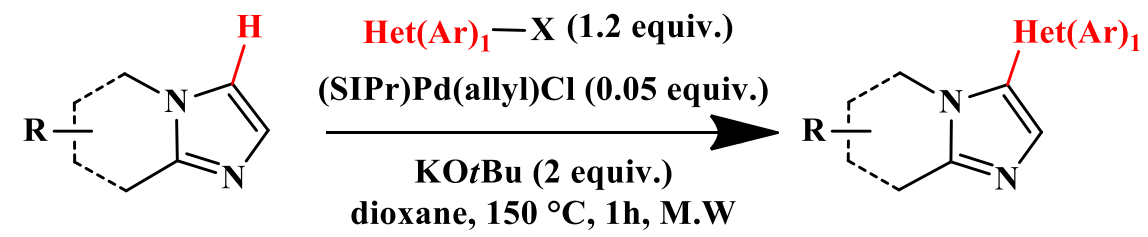

$\mathbf{R}=\mathbf{H}, \mathbf{C l}, \quad \mathbf{X}=$ Br or $\mathbf{I}$

$\operatorname{Het}(\mathrm{Ar})_{1}=$ Phenyl, tolyl, thienyl, pyridin-3-yl

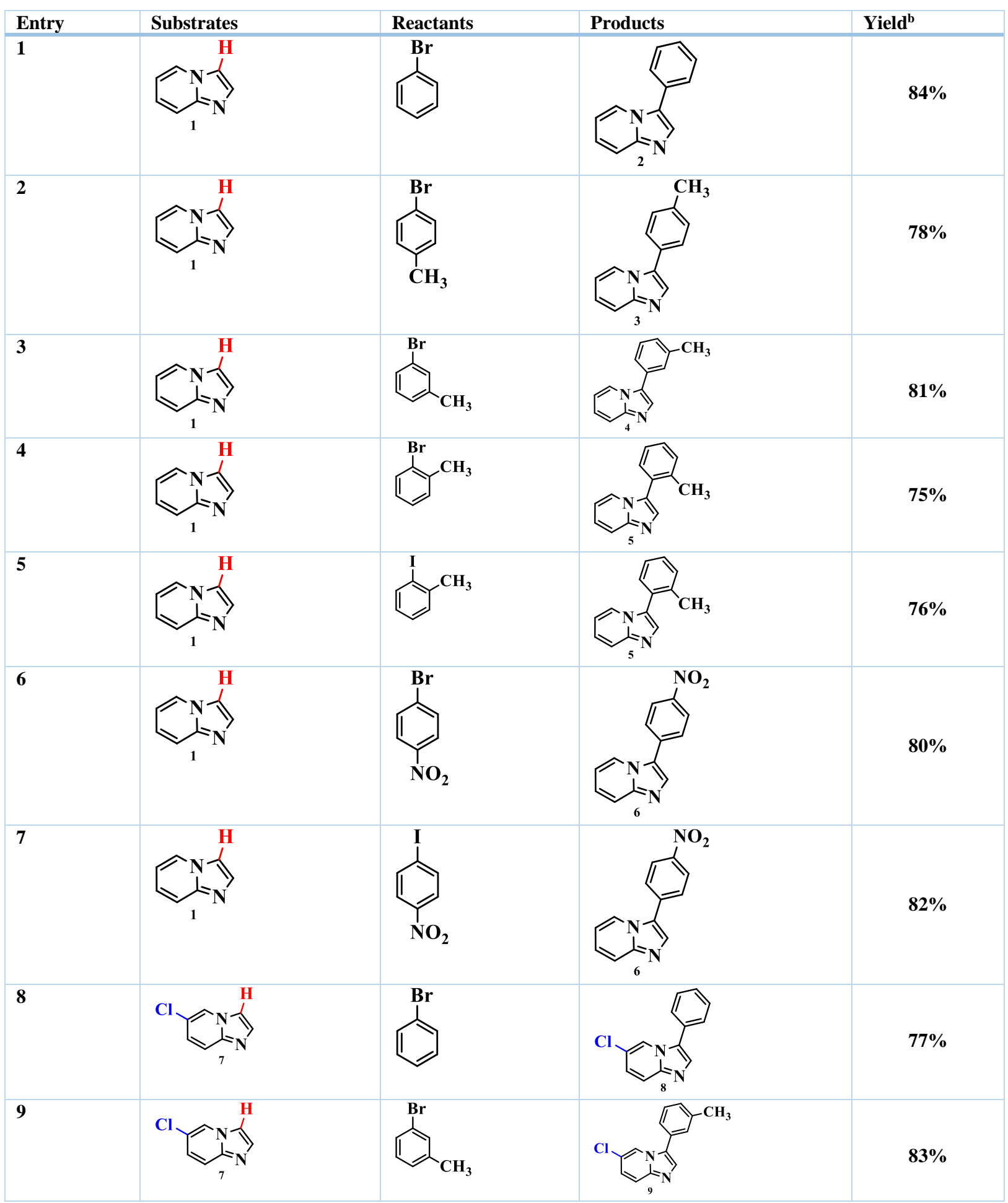




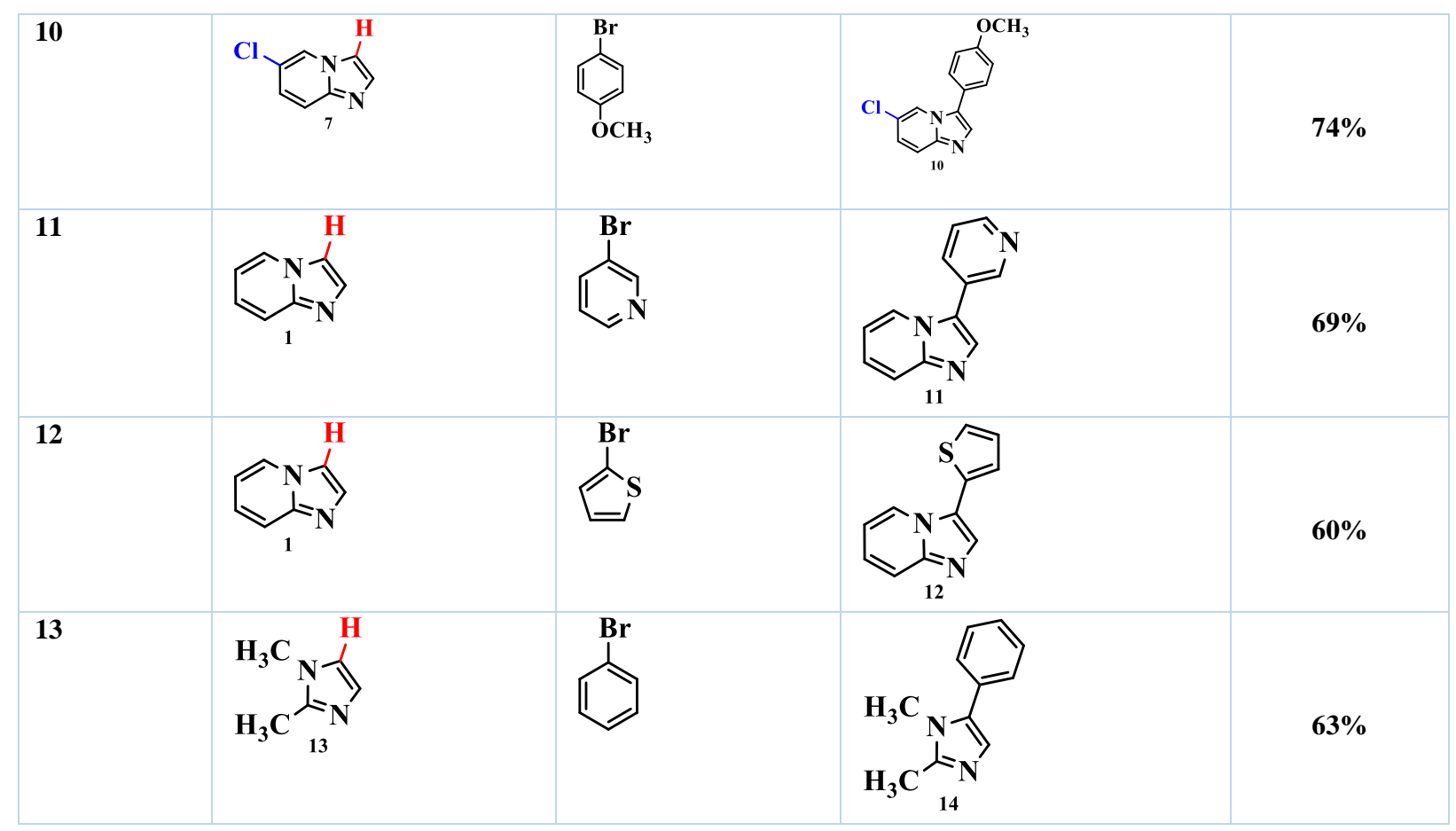

${ }^{a}$ Reaction conditions: (SIPr)Pd(allyl)Cl (0.05 equiv.), $\mathrm{Ar}_{1}$ - $\mathrm{Br}$ (1.2 equiv.), $\mathrm{KO} t \mathrm{Bu}$ (2 equiv.), 2 ml of dioxane $150^{\circ} \mathrm{C}, 1 \mathrm{~h}, \mathrm{M} . \mathrm{W} .{ }^{\mathrm{b}}$ Isolated yields

Under the optimized reaction conditions for direct arylation, we next examined Pd-catalyzed SuzukiMiyaura cross-coupling of 6-chloroimidazo [1,2-a] pyridine derivatives. Gratifyingly, the starting materials 7 and $15^{30 a}$ could be efficiently functionalized at 6-position using boronic acids as coupling partners under following conditions [(SIPr)Pd(allyl)Cl (5 mol\%), KOtBu (2 equiv.), dioxane at $150^{\circ} \mathrm{C}$ for 1 hour under M.W. This procedure allowed to isolate the desired products $\mathbf{1 6}$ ${ }^{30 \mathrm{~b}, 32}, \mathbf{1 7}^{30 \mathrm{~b}, 32}, \mathbf{1 8}$ and $\mathbf{1 9}^{30 \mathrm{~b}}$ in good yields (64-80\%, Scheme 2).

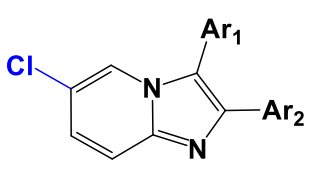

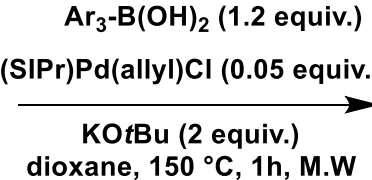

$7: A r_{1}=H ; A r_{2}=H$ dioxane, $150^{\circ} \mathrm{C}, 1 \mathrm{~h}, \mathrm{M} . \mathrm{W}$

15: $A r_{1}=3$-pyridyl $; \mathrm{Ar}_{2}=\mathrm{Ph}$<smiles>CC(C)(C)c1cc2c([14CH3])c([14CH3])nc([14CH3])n2c1</smiles><smiles>CSc1ccc(-c2ccc3nccn3c2)cc1</smiles>

$16(64 \%)$<smiles>CC=CCCC</smiles>

$17(80 \%)$<smiles>Cc1ccc(-c2ccc3nccn3c2)cc1</smiles>

$18(76 \%)$<smiles>CSc1ccc(-c2ccc3nc(-c4ccccc4)c(-c4cccnc4)n3c2)cc1</smiles>

$19(72 \%)$

Scheme 2. Suzuki-Miyaura coupling of 6-chloroimidazo[1,2-a] pyridine.

\section{Conclusion}

In summary, we have reported a new catalytic system that provides a direct access to a wide range of 3-aryl-imidazo[1,2- $a$ ]pyridines $\quad \mathrm{C}-\mathrm{H}$ direct arylation under microwave-irradiation. The developed reaction conditions were also successfully applied to the direct arylation of 1, 2-dimethyl-1 $H$ imidazole. Moreover, the catalyst system based on (SIPr)Pd(allyl)Cl complex was highly effective for Suzuki-Miyaura coupling reaction of 6-chloroimidazo[1,2- $a]$ pyridines with boronic acids 
under the same reaction conditions developed for direct arylation.

\section{Experimental}

Microwaves-assisted reactions were carried out in a CEM Initiator microwave synthesis instrument. Melting points were determined with Büchi SMP-20 melting point apparatus and were uncorrected. ${ }^{1} \mathrm{H}$ NMR and ${ }^{13} \mathrm{C}$ NMR were recorded on a Bruker Avance DPX250 spectrometer $\left({ }^{1} \mathrm{H}, \quad 250 \mathrm{MHz}\right.$, $\left.{ }^{13} \mathrm{C}, 63 \mathrm{MHz}\right)$ using tetramethylsilane as the internal standard, multiplicities were determined by the DEPT 135 sequence. Chemical shifts were reported in parts per million (ppm, $\delta$ units). Coupling constants were reported in units of hertz $(\mathrm{Hz})$. Splitting patterns were designated as s, singlet; $\mathrm{d}$, doublet, $\mathrm{t}$, triplet, $\mathrm{m}$, multiplet. All commercial solvents were used without further purification. The following solvents and reagents have been abbreviated: ethyl acetate (EtOAc), ethanol (EtOH), and petroleum ether (PE). Column chromatography was carried out using Silica gel 60N (spherical, neutral, 40-63 $\mu \mathrm{m}$, Merck). Thin layer chromatography (TLC) was carried out on Merck silica gel $60 \mathrm{~F}_{254}$ percolated plates. Visualization was made with ultraviolet light. Allyl[1,3-bis(2,6diisopropylphenyl)-2-imidazolidinylidene] chloro palladium (II), 97\%, Synonym: (SIPr)Pd(allyl)Cl, (Sigma-Aldrich). All reported yields were isolated.

General Procedure for Palladium-Catalyzed Direct (Hetero)Arylation under Microwave Irradiation (Scheme 1, Table 1).

Typically, to a solution of imidazo[1,2-a] pyridine derivatives $(100 \mathrm{mg})$ dissolved in $2 \mathrm{~mL}$ of dioxane in a vial microwave tube with a stir bar were added, aryl halide (1.2 equiv.), potassium tert-butoxide $(\mathrm{KO} t \mathrm{Bu})(2$ equiv.) and (SIPr)Pd(allyl)Cl (5 mol\%). The vial was sealed with a silicon septum and subjected to microwave irradiation at $150^{\circ} \mathrm{C}$ for $1 \mathrm{~h}$ with stirring. The reaction mixture was allowed to cool to room temperature, and the solution was diluted with $\mathrm{H}_{2} \mathrm{O}$ then extracted with $(3 \times 15 \mathrm{~mL}$ of dichloromethane. The combined organic layer was dried over anhydrous $\mathrm{MgSO}_{4}$ and concentrated under vacuum. The residue was purified by column chromatography on silica gel (EtOAc/ hexane) to give the desired products 2-6, 8-12 and 14 .

\section{3-Phenyl-imidazo[1,2-a]pyridine ${ }^{30 \mathrm{a}, 35,36}$.}

The generale procedure afforded $138 \mathrm{mg}$ ( $84 \%$ yield) of the title compound. ${ }^{1} \mathrm{H}$ NMR and ${ }^{13} \mathrm{C}$ NMR spectrum matched that of the literature.

3-(p-Tolyl)imidazo[1,2,a]pyridine $3^{35,36}$.

The generale afforded $138 \mathrm{mg}(78 \%$ yield $)$ of the title compound. Compound 3was identified by comparison of NMR data with those reported in the literature.
3-(m-Tolyl)imidazo[1,2,a]pyridine $4^{30 \mathrm{a}, 35}$.

The generale procedure afforded $143 \mathrm{mg}$ ( $81 \%$ yield) of the title compound. ${ }^{1} \mathrm{H}$ NMR and ${ }^{13} \mathrm{C}$ NMR spectrum matched that of the literature.

3-(o-Tolyl)imidazo[1,2,a]pyridine $5^{35}$.

The generale procedure afforded (133 mg $75 \%$ yield and $134 \mathrm{mg} 76 \%$ yield) of the title compound. ${ }^{1} \mathrm{H}$ NMR and ${ }^{13} \mathrm{C}$ NMR spectrum matched that of the literature.

3-(4-Nitrophenyl)-imidazo[1,2-a] pyridine $6^{36}$.

The generale procedure afforded (163 mg 80\% yield and $167 \mathrm{mg} 82 \%$ yield) of the title compound. ${ }^{1} \mathrm{H}$ NMR and ${ }^{13} \mathrm{C}$ NMR spectrum matched that of the literature.

\section{6-Chloro-3-phenyl-imidazo[1,2-a] pyridine $8^{30 \mathrm{a}}$.}

The generale procedure afforded $115 \mathrm{mg}$ (77\% yield) of the title compound. ${ }^{1} \mathrm{H}$ NMR and ${ }^{13} \mathrm{C}$ NMR spectrum matched that of the literature.

6-Chloro-3-(m-tolyl)-imidazo[1,2-a] pyridine $9^{30 a}$. The generale procedure for formation reaction afforded $132 \mathrm{mg}$ (83\% yield) of the title compound. ${ }^{1} \mathrm{H}$ NMR and ${ }^{13} \mathrm{C}$ NMR spectrum matched that of the literature.

\section{6-Chloro-3-(4-methoxyphenyl)} pyridine $10^{37}$.

imidazo[1,2,a]

The generale procedure afforded $125 \mathrm{mg}$ (74\% yield) of the title compound. ${ }^{1} \mathrm{H}$ NMR and ${ }^{13} \mathrm{C}$ NMR spectrum matched that of the literature.

3-Pyridin-3-ylimidazo[1,2-a] pyridine $1^{30 \mathrm{a}, \mathrm{b}, 36,38}$. The generale procedure afforded $114 \mathrm{mg}$ (69\% yield) of the title compound. ${ }^{1} \mathrm{H}$ NMR and ${ }^{13} \mathrm{C}$ NMR spectrum matched that of the literature.

\section{3-(Thiophen-2-yl)imidazo[1,2-a] pyridine $12^{38}$.}

The generale procedure afforded $102 \mathrm{mg}$ (60\% yield) of the title compound. ${ }^{1} \mathrm{H}$ NMR and ${ }^{13} \mathrm{C}$ NMR spectrum matched that of the literature.

\section{1,2-Dimethyl-5-phenyl-1H-imidazole 14 $^{36,39}$.}

The generale procedure afforded $112 \mathrm{mg}$ (63\% yield) of the title compound. ${ }^{1} \mathrm{H}$ NMR and ${ }^{13} \mathrm{C}$ NMR spectrum matched that of the literature.

General Procedure for Palladium-Catalyzed Suzuki Coupling Reaction under Microwave Irradiation (Scheme 2).

Typically, to a solution of 6-chloroimidazo[1,2-a] pyridine $(100 \mathrm{mg}, 0.66 \mathrm{mmol})$ dissolved in $2 \mathrm{ml}$ of dioxane in a vial microwave tube with a stir bar were added, aryl boronic acid (1.2 equiv.), potassium tertbutoxide (KO $t \mathrm{Bu})$ (2 equiv.) and ( $\mathrm{SIPr}) \mathrm{Pd}($ allyl)Cl ( $5 \mathrm{~mol} \%$ ). The vial was sealed with a silicon septum and subjected to microwave irradiation at $150^{\circ} \mathrm{C}$ for $1 \mathrm{~h}$ with stirring. The reaction mixture was allowed to cool to room temperature and the solution was 
diluted with $\mathrm{H}_{2} \mathrm{O}$ then extracted with $(3 \times 15 \mathrm{~mL}$ of dichloromethane. The combined organic layer was dried over anhydrous $\mathrm{MgSO}_{4}$ and concentrated under vacuum. The residue was purified by column chromatography on silica gel (EtOAc/ Hexane) to give the desired products 16-19.

\section{6-p-Tolylimidazo[1,2-a] pyridine 18.}

The general procedure for Suzuki-Miyaura afforded $180 \mathrm{mg}$ (76\% yield) as an oil of the title compound. ${ }^{1} \mathrm{H}$ NMR $\left(250 \mathrm{MHz}, \mathrm{CDCl}_{3}\right) \delta=2.43(\mathrm{~s}, 3 \mathrm{H}), 7.30$ $(\mathrm{d}, J=7.5 \mathrm{~Hz}, 2 \mathrm{H}), 7.52-7.38(\mathrm{~m}, 3 \mathrm{H}), 7.74-7.60$ $(\mathrm{m}, 3 \mathrm{H}), 8.29(\mathrm{~s}, 1 \mathrm{H})$.

${ }^{13} \mathrm{C}$ NMR $\left(63 \mathrm{MHz}, \mathrm{CDCl}_{3}\right): \delta=21.1\left(\mathrm{CH}_{3}\right), 112.6$ $(\mathrm{CH}), 117.6(\mathrm{CH}), 122.7(\mathrm{CH}), 125.2(\mathrm{CH}), 126.7$ (2xCH), $129.8(2 \times C H), 133.9(\mathrm{CH}), 134.3(\mathrm{C}), 137.7$ (2C), 144.7 (C). IR: $1512(\mathrm{C}=\mathrm{C}), 1669(\mathrm{C}=\mathrm{N})$. HRMS (+ESI) m/z: $[\mathrm{M}+\mathrm{H}]^{+}$calculated for $\mathrm{C}_{14} \mathrm{H}_{12} \mathrm{~N}_{2}$ : 209.1069, found, 209.1073.

Compounds $16^{30 \mathrm{~b}}, \mathbf{1 7}^{32 \mathrm{a}}$ and $\mathbf{1 9}^{30 \mathrm{~b}}$ were identified by comparison of their NMR data with those reported in the literature.

\section{References}

1- (a) M. Gerlach, C. Maul, WO 01/27119; (b) B. Sundermann, C. Maul, H.-H. Hennies, J. Schneider, WO 02/30428; (c) S. T. Hodgson, US005538970; (d) H. Nagaya, Y. Kawano, T. Kashihara, WO 01/34152; (e) K. Fuchs, M. Romig, K. Mendla, H. Briem, K. Fechteler, WO02/14313; (k) A. P. Thomas, G. A. Breault, J. F. Beattie, P. J. Jewsbury, WO 01/14375.

2- M. Hayakawa, H. Kaizawa, K. Kawaguchi, N. Ishikawa, T. Koizumi, T. Ohishi, M. Yamano, M. Okada, M. Ohta, S. Tsukamoto, F. I. Raynaud, M. D. Waterfield, P. Parker, P. Workman, Synthesis and biological evaluation of imidazo[1,2- $a$ ] pyridine derivatives as novel PI3 kinase p1 $10 \alpha$ inhibitors. Bioorg. Med. Chem., 2007, 15, 403-412.

3- G. Trapani, M. Franco, A. Latrofa, L. Ricciardi, A. Carotti, M. Serra, E. Sanna, G. Biggio, G. Liso, Novel 2-Phenylimidazo[1,2-a] pyridine Derivatives as Potent and Selective Ligands for Peripheral Benzodiazepine Receptors: Synthesis, Binding Affinity, and in Vivo Studies. J. Med. Chem., 1999, 42, 3934-3941.

4- R. Ducray, I. Simpson, F. H. Jung, J. W. M. Nissink, P. W. Kenny, M. Fitzek, G. E. Walker, L. T. Ward, K. Hudson, Discovery of novel imidazo[1,2-a] pyridines as inhibitors of the insulin-like growth factor-1 receptor tyrosine kinase. Bioorg. Med. Chem. Lett., 2011, 21, 4698-4701.

5- L. Almirante, L. Polo, A. Mugnaini, E. Provinciali, P. Rugarli, A. Biancotti, A. Gamba, W. Murmann, Derivatives of Imidazole. I. Synthesis and Reactions of Imidazo[1,2- $\alpha$ ] pyridines with Analgesic, Antiinflammatory, Antipyretic, and Anticonvulsant Activity. J. Med. Chem., 1965, 8, 305-312.
6- G. Guillaumet, S. Berteina-Raboin, S. El Kazzouli, P. Delagrange, D.-H. Caignard, PCT, Int. Appl., WO 2006027474, 2006. Chem. Abstract.,2006, 144, 254132.

7- (a) M. Lhassani, O. Chavignon, J. M. Chezal, J. C. Teulade, J. P. Chapat, R. Snoeck, G. Andrei, J. Balzarini, E. De Clercq, A. Gueiffier, Synthesis and antiviral activity of imidazo[1,2- $a$ ] pyridines. J. Med. Chem., 1999, 34, 271-274. (b) k. S. Gudmundsson, J. C. Drach, L. B. Townsend, Synthesis of Imidazo[1,2-a] pyridine C-Nucleosides with an Unexpected Site of Ribosylation, J. Org. Chem., 1997, 62, 3453-3459. (c) C. Hamdouchi, J. de Blas, M. del Prado, J. Gruber, B. A. Heinz, L. Vance, 2-Amino-3-substituted-6-[(E)-1phenyl-2-(N-methyl carbam-oyl) vinyl]imidazo $[1,2-a]$ pyridines as a Novel Class of Inhibitors of Human Rhinovirus: Stereospecific Synthesis and Antiviral Activity. J. Med. Chem., 1999, 42, 50-59. (d) K. S. Gudmundsson, J. D. Williams, J. C. Drach, L. B. Townsend, Synthesis and Antiviral Activity of Novel Erythrofuranosyl Imidazo[1,2- $a$ ] pyridine C-Nucleosides Constructed via Palladium Coupling of Iodoimidazo[1,2- $a]$ pyridines and Dihydrofuran. J. Med. Chem., 2003, 46, 1449-1455.

8- J. J. Kaminsky, A. M. Doweyko, Antiulcer Agents. 6. Analysis of the in Vitro Biochemical and in Vivo Gastric Antisecretory Activity of Substituted Imidazo[1,2- $a$ ] pyridines and Related Analogues Using Comparative Molecular Field Analysis and Hypothetical Active Site Lattice Methodologies. J. Med. Chem., 1999, 40, 427-436;

9- Y. Rival, G. Grassy, G. Michael, Synthesis and Antibacterial Activity of Some Imidazo[1,2- $\alpha]$ pyrimidine Derivatives. Chem. Pharm. Bull., 1992, 40, 1170-1176;

10- P. J. Beeswick, I. B. Campbell, A. Naylor, PCT. Int. Appl. WO 9631 509, 1996; Chem. Abst., 1997,126, 8117.

11 - (a) G. Trapani, M. Franco, A. Latrofa, L. Ricciardi, A. Carotti, M. Serra, E. Sanna, G. Biggio, G. Liso, Novel 2-Phenylimidazo $[1,2-a]$ pyridine Derivatives as Potent and Selective Ligands for Peripheral Benzodiazepine Receptors: Synthesis, Binding Affinity, and in Vivo Studies. J. Med. Chem., 1999, 42, 3934-3941. (b) G. Trapani, M. Franco, L. Ricciardi, A. Latrofa, G. Genchi, E. Sanna, F. Tuveri, E. Gagetti, G. Biggio, G. Liso, Synthesis and Binding Affinity of 2Phenylimidazo[1,2-a] pyridine Derivatives for both Central and Peripheral Benzodiazepine Receptors. A New Series of High-Affinity and Selective Ligands for the Peripheral Type. J. Med. Chem., 1997, 40, 3109-3118.

12- P. J. Sanfilippo, M. Urbanski, J. B. Press, B. Dubinsky, J. B. Jr. Moore, Regiospecific synthesis of 3-substituted imidazo[1,2-a] pyridines, imidazo[1,2- $a$ ] pyrimidines, and 
imidazo[1,2-c] pyrimidine. J. Med. Chem., 1991, 34, 2060-2067.

13- K. Fuchs, M. Romig, K. Mendla, H. Briem, K. Fechteler, WO 14 131, 2002, Chem. Abstr., 2002, 136, 183824r.

14- Z. P. Zhuang, M. P. Kung, A. Wilson, C. W. Lee, K. Plössl, C. Hou, D.M. Holtzman, H. F. Kung, Structure-Activity Relation ship of Imidazo[1,2-a]pyridines as Ligands for Detecting $\beta$-Amyloid Plaques in the Brain. J. Med. Chem., 2003, 46, 237-243.

15- H. Franke, J. Geisler, U. Hartfiel, W. Franke, G. Dorfmeister, M. Ganzer, G. Johahann, R. Rees, Ger. Offen. DE. 4120 108, 1991; Chem. Abstr., 1992, 118, 213075v.

16- K. F. Byth, J. D. Culshaw, S. Green, S. Oakes, A. P. Thomas, Imidazo[1,2-a] pyridines. Part 2: SAR and optimisation of a potent and selective class of cyclin-dependent kinase inhibitors. Bioorg. Med. Chem. Lett., 2004, 14, 2245-2248.

17- A. C. Humphries, E. Gancia, M. T. Gilligan, S. Goodacre, D. Hallett, K. J. Merchant, S. R. Thomas, 8-Fluoroimidazo[1,2-a] pyridine: Synthesis, physicochemical properties and evaluation as a bioisosteric replacement for imidazo[1,2- $a$ ] pyrimidine in an allosteric modulator ligand of the GABAA receptor. Bioorg. Med. Chem. Lett., 2006, 16, 1518-1522.

18- Y. Abe, H. Kayakiri, S. Satoh, T. Inoue, Y. Sawada, K. H. Imai, A Novel Class of Orally Active Non-Peptide Bradykinin B2 Receptor Antagonists. 1. Construction of the Basic Framework. J. Med. Chem., 1998, 41, 564-578.

19- (a) T. Okubo, R. Yoshikawa, S. Chaki, S. Okuyamac, A. Nakazato, Design, synthesis and structure-affinity relationships of aryloxyanilide derivatives as novel peripheral benzodiazepine receptor ligands. Bioorg. Med. Chem., 2004, 12, 423-438; (b) S. Z. Langer, S. Arbilla, J.

Benavides, B. Scatton, Zolpidem and Alpidem: Two imidazopyridines with selectivity for $\omega \_1$-and $\omega \_3$-receptor subtypes. Adv. Biochem. Psychopharmacol., 1990, 46, 61-72.

20- (a) K. J. Holm, K. L. Goa, Zolpidem. Drugs. 2000, 59, 865-889; (b) N. Hsua, S. K. Jha, T. Coleman, M. Frank, Paradoxical effects of the hypnotic Zolpidem in the neonatal ferret. Behav. Brain Res., 2009, 201, 233-236;

21- (a) K. Mizushige, T. Ueda, K. Yukiiri, H. Suzuki, Olprinone: a phosphodiesterase III inhibitor with positive inotropic and vasodilator effects. Cardiovasc. Drug Rev., 2002, 20, 163-174; (b) T. Ueda, K. Mizushige, K. Yukiiri, T. Takahashi, M. Kohno, Improvement of cerebral blood flow by olprinone, a phosphodiesterase-3 inhibitor, in mild heart failure. CerebroVasc. Dis., 2003, 16, 396-401; (c) K. Ochiai, S. Takita, A. Kojima, T. Eiraku, N. Ando, K. Iwase, T. Kishi, A. Ohinata, Y. Yageta, T. Yasue, D. R. Adams, Y. Kohno, Phosphodiesterase inhibitors. Part 4: Design, synthesis and structure-activity relationships of dual PDE3/4-inhibitory fused bicyclic heteroaromatic-4,4-dimethylpyrazolones. Bioorg. Med. Chem. Lett., 2012, 22, 5833-5838.

22- J. Koubachi, S. El Kazzouli, M. Bousmina, G. Guillaumet, Functionalization of Imidazo[1,2- $a$ ] pyridines by Means of Metal-Catalyzed Cross-Coupling Reactions. Eur. J. Org. Chem. 2014, 5119-5138.

23- (a) S. El Kazzouli, J. Koubachi, N. El Brahmi, G. Guillaumet, Advances in direct $\mathrm{C}-\mathrm{H}$ arylation of 5, 5-6, 5-and 6, 6-fused-heterocycles containing heteroatoms (N, O, S). RSC Adv., 2015, 5, 15292-15367; (b) U. Sharma, A. Modak, S. Maity, A. Maji, D. Maiti, Direct Arylation via C-H Activation, RSC Catalysis Series No. 21, From the book: New Trends in Cross-Coupling: Theory and Applications, ed. by T. J. Colacot, 2014, 551- 609.

24- D. Enders, O. Niemeier, A. Henseler, Organocatalysis by N-heterocyclic carbenes. Chem. Rev., 2007, 107, 5606-5655.

25- (a) N-Heterocyclic Carbenes: Effective Tools for Organometallic Synthesis-Wiley-VCH, 568 pages, September 2014, ed. byS. P. Nolan, ISBN: 978-3-527-33490-2, Print ISBN: 978-3527-33490-2, ePDF ISBN: 978-3-527-67125-0; (b) A. Charroire, and P. S. Nolan, Advances in $\mathrm{C}-\mathrm{C}$ and $\mathrm{C}-\mathrm{X}$ Coupling Using Palladium-NHeterocyclic Carbene (Pd-NHC) Complexes, RSC Catalysis Series No. 21, From the book: New Trends in Cross-Coupling: Theory and Applications, ed. byT. J. Colacot, 2014, 139, (c) S. Díez-González, N. Marion, S. P. Nolan, $\mathrm{N}$-heterocyclic carbenes in late transition metal catalysis. Chem. Rev., 2009, 109, 3612-3676.

26- (a) X.-B. Lan, F.-M. Chen, B.-B. Ma, D.-S. Shen, F.-S. Liu, Pd-PEPPSI Complexes Bearing Bulky [(1,2-Di-(tert-butyl) acenaphthyl] (DtBuAn) on N-Heterocarbene Backbones: Highly Efficient for Suzuki-Miyaura Cross-Coupling under Aerobic Conditions. Organometallics, 2016, 35, 3852-3860; (b) P. Yin, M. Y. Wong, J. Thamb, T.-P Loh, Nucleoside analogs as a rich source of antiviral agents active against arthropod-borne flaviviruses. Org. Chem. Front., 2014, 1, 1266-1269; (c) M. J. Cawley, F. G. N. Cloke, R. J. Fitzmaurice, S. E. Pearson, J. S. Scott, S.Caddick, Development of a practical Buchwald-Hartwig amine arylation protocol using a conveniently prepared (NHC) $\mathrm{Pd}(\mathrm{R}$ allyl)Cl catalyst. Org. Biomol. Chem., 2008, 6, 2820-2825; (d) O. Navarro, Marion, J. Mei, S. P. Nolan, Rapid room temperature BuchwaldHartwig and Suzuki-Miyaura couplings of heteroaromatic compounds employing low catalyst loadings. Chem. Eur. J., 2006, 12, 5142-5148;(e) N. Marion, O. Navarro, J. Mei, E. D. Stevens, N. M. Scott, S. P. Nolan, Modified (NHC)Pd(allyl)Cl $(\mathrm{NHC}=\mathrm{N}-$ Heterocyclic Carbene) Complexes for RoomTemperature Suzuki-Miyaura and 
Buchwald-Hartwig Reactions. J. Am. Chem. Soc., 2006, 128, 4101-4111; (f) O. Navarro, H. Kaur, P. Mahjoor, S. P. Nolan, CrossCoupling and Dehalogenation Reactions Catalyzed by (N-Heterocyclic carbene)Pd(allyl)Cl Complexes. J. Org. Chem., 2004,69, 3173-3180; (g) L. J. Gooßen, J. Paetzold, O. Briel, A. Rivas-Nass, R. Karch, B. Kayserc, Buchwald-Hartwig Aminations of Aryl Chlorides: A Practical Protocol Based on Commercially Available Pd(0)-NHC Catalysts. Synlett., 2005, 36, 275-278; (h) R. Singh, S. P. Nolan, An efficient and mild protocol for the $\alpha$-arylation of ketones mediated by an (imidazol2-ylidene) palladium(acetate) system. J. Organomet. Chem., 2005, 690, 5832-5840; (i) O. Navarro, N. Marion, N. M. Scott, J. Gonzalez, D. Amoroso, A. Bell, S. P. Nolan, Synthesis of novel (NHC)Pd(acac)Cl complexes $(\mathrm{acac}=$ acetyl acetonate $)$ and their activity in cross-coupling reactions. Tetrahedron, 2005,61, 9716-9722; (j) O. Navarro, N. Marion, Y. Oonishi, R. A. Kelly, S. P. Nolan, Suzuki-Miyaura, $\alpha$-Ketone Arylation and Dehalogenation Reactions Catalyzed by a Versatile N-Heterocyclic Carbene-Palladacycle Complex. J. Org. Chem., 2006,71, 685-692; (k) K. Matsubara, H. Okazaki, M. J. Senju, Polycondensation of haloarylketones catalyzed by palladium compounds bearing N-heterocyclic carbene (NHC) ligands. J. Organomet. Chem. 2006, 691, 3693-3699.

27- (a) P. V. Kumar, W.-S. Lin, J.-S. Shen, D. Nandi, H. M. Lee, Direct C5-arylation reaction between imidazoles and aryl chlorides catalyzed by palladium complexes with phosphines and N-heterocyclic carbenes. Organometallics. 2011, 30,5160-5169; (b) S. Demir, I. Özdemir, H. Arslan, D. J. VanDerveer, Butylene linked palladium $\mathrm{N}$-heterocyclic carbene complexes: Synthesis and catalytic properties. J. Organomet. Chem., 2011, 696,2589-2593; (c) B. B. Touré, B. S. Lane, D. Sames, Catalytic C- H arylation of SEM-protected azoles with palladium complexes of NHCs and phosphines. Org. Lett., 2006, 8, 1979-1982; (d) I. Ozdemir, Y. Gök, Ö. Özeroğlu, M. Kaloğlu, H. Doucet, C. Bruneau, N-Heterocyclic Carbenes: Useful Ligands for the Palladium-Catalysed Direct C5 Arylation of Heteroaromatics with Aryl Bromides or Electron-Deficient Aryl Chlorides. Eur. J. Inorg. Chem., 2010,1798-1805; (e) A. R. Martin, A. Chartoire, A. M. Z. Slawin, S. P. Nolan, Extending the utility of [Pd (NHC)(cinnamyl) $\mathrm{Cl}$ ] precatalysts: Direct arylation of heterocycles. Beilstein J. Org. Chem., 2012, 8, 1637-1643; (f) M. Lesieur, F. Lazreg, C. S. Cazin, A cooperative $\mathrm{Pd}-\mathrm{Cu}$ system for direct $\mathrm{C}-\mathrm{H}$ bond arylation. J. Chem. Commun., 2014, 50, 8927-8929; (g) D. Ghosh, H. M. Lee, Efficient Pd-catalyzed direct arylations of heterocycles with unreactive and hindered aryl chlorides. Org. Lett., 2012, 14, 5534-5537.

28- (a) J. Koubachi, N. El Brahmi, G. Guillaumet, S. El Kazzouli, Oxidative alkenylation of fused bicyclic heterocycles. Eur. J. Org. Chem., 2019, 2568-2586. (b) S. Faarasse, S. El Kazzouli, F. Suzenet, G. Guillaumet, Palladium-Catalyzed C3-Arylations of 1H- and 2H-Pyrazolo[4,3-b] pyridines on Water. J. Org. Chem., 2018, 83, 12847-12854. (c) S. Faarasse, S. ElKazzouli, M. Naas, J. Jouha, F. Suzenet, G. Guillaumet, "On Water" Direct C-3 Arylation of 2HPyrazolo[3,4-b] pyridines. J. Org. Chem., 2017, 82, 12300-12306. (d) M. Naas, S. El Kazzouli, E. M.Essassi, M. Bousmina, G.Guillaumet, Palladium-catalyzed oxidative direct $\mathrm{C} 3$-and C7-alkenylations of indazoles: Application to the synthesis of Gamendazole. Org. Lett., 2015, 17, 4320-4323.

29- (a) S. El Kazzouli, S. Berteina-Raboin, A. Mouaddib, G. Guillaumet, Solid-phase synthesis of imidazo[1,2-a] pyridines and imidazo[1,2- $a]$ pyrimidines. Tetrahedron Lett., 2003, 44, 6265-6267; (b) S. El Kazzouli, A. Berthault, S. Berteina-Raboin, A. Mouaddib, G. Guillaumet, Solution and solid phase functionalization of imidazo[1,2- $a]$ pyridines. Lett. Org. Chem., 2005, 2, 184-187.

30- (a) J. Koubachi, S. El Kazzouli, S. BerteinaRaboin, A. Mouaddib, G. Guillaumet, Regioselective palladium-catalyzed arylation and heteroarylation of imidazo[1,2-a] pyridines. Synlett., 2006, 19, 3237-3242; (b) J. Koubachi, S. El Kazzouli, S. Berteina-Raboin, A. Mouaddib, G. Guillaumet, Synthesis of Polysubstituted Imidazo[1,2-a] pyridines via Microwave-Assisted One-Pot Cyclization/Suzuki Coupling/PalladiumCatalyzed Heteroarylation. J. Org. Chem., 2007, 72, 7650-7655; (c) J. Koubachi, S. BerteinaRaboin, A. Mouaddib, G. Guillaumet, Intramolecular arylation reactions: first efficient synthesis of novel fused pyridoimidazoquinolinones or pyridoimidazo-azepinones libraries. Tetrahedron, 2010, 66, 1937-1946.

31- (a) J. Koubachi, S. El Kazzouli, S. BerteinaRaboin, A. Mouaddib, G. Guillaumet, New and efficient palladium (0)-mediated microwaveassisted direct C3 alkenylation of imidazo[1,2- $a$ ] pyridines. Synthesis, 2008, 16,2537-2542; (b) J. Koubachi, S. Berteina-Raboin, A. Mouaddib, G. Guillaumet, $\mathrm{Pd} / \mathrm{Cu}$-Catalyzed Oxidative C-H Alkenylation of Imidazo[1,2- $a$ ] pyridines, Synthesis, 2009, 2, 271-276.

32- (a) J. Koubachi, S. El Kazzouli, S. BerteinaRaboin, A. Mouaddib, G. Guillaumet, Efficient microwave-assisted Suzuki-Miyaura crosscoupling reaction of 6-haloimidazo[1,2- $a$ ] pyridines. J. Mar. Chim. Heterocycl., 7, 2008, 1-9; (b) A. El Akkaoui, J. Koubachi, S. Berteina-Raboin, A. Mouaddib, 
G. Guillaumet, Pd-catalyzed regiocontrolled Sonogashira and Suzuki cross-coupling reaction of 3, 6-dihalogenoimidazo [1,2- $a$ ] pyridines: One-pot double-coupling approach. Tetrahedron, 2011, 67, 7128-7138.

33- M. S. Viciu, R. F. Germaneau, O. NavarroFernandez, E. D. Stevens, S. P. Nolan, Activation and reactivity of (NHC) $\mathrm{Pd}$ (allyl) $\mathrm{Cl}$ ( $\mathrm{NHC}=\mathrm{N}$-heterocyclic carbene) complexes in cross-coupling reactions. Organometallics, 2002, 21, 5470-5472.

34- M. S. Viciu, R. F. Germaneau, S. P. Nolan, Well-defined, air-stable (NHC) Pd (Allyl) $\mathrm{Cl}$ $(\mathrm{NHC}=\mathrm{N}$-heterocyclic carbene) catalysts for the arylation of ketones. Org. Lett., 2002, 4, 4053-4056.

35- Q-X. Liu, B-Y. He, P-C. Qian, L-X Shao, $\mathrm{N}$-Heterocyclic carbene-palladium (ii)-1methylimidazole complex catalyzed direct $\mathrm{C}-\mathrm{H}$ bond arylation of imidazo[1,2- $a$ ] pyridines with aryl chlorides. Org. Biomol. Chem., 2017, 15, 1151-1154.
36- D. Nandi, S. S. Siwal, K. Mallick. Mono Arylation of Imidazo[1,2-a] pyridine and 1,2-dimethyl Imidazole: Application of Carbon Nitride Supported Palladium Catalyst. ChemistrySelect 2017, 2, 1747-1752.

37- S. K. Rasheed, D. N. Rao, P. Das, Coppercatalyzed inter-and intramolecular $\mathrm{C}-\mathrm{N}$ bond formation: synthesis of benzimidazole-fused heterocycles. J. Org. Chem., 2015, 80, 9321-9327.

38- F-M. Chen, F-D. Huang, X-Y. Yao, T. Li, F-S, Liu, Direct $\mathrm{C}-\mathrm{H}$ heteroarylation by an acenaphthyl-based $\alpha$-diimine palladium complex: improvement of the reaction efficiency for bi (hetero) aryls under aerobic conditions. Org. Chem. Front. 2017, 4, 2336-2342.

39- X.-X. He, Y. Li, B.-B. Ma, Z. Ke, F.-S, Liu, Sterically Encumbered Tetraarylimidazolium Carbene Pd-PEPPSI Complexes: Highly Efficient Direct Arylation of Imidazoles with Aryl Bromides under Aerobic Conditions. Organometallics, 2016, 35, 2655-2663. 